\title{
Pengaruh suplementasi serat Psyllium husk dan diet rendah kalori seimbang terhadap berat badan, kadar kolesterol high-density lipoprotein, dan trigliserida serum pada obes I
}

The effect of soluble fiber supplementation (Psyllium husk) were balanced-deficit calories diet on body weight, serum high-density lipoprotein cholesterol, and triglyceride concentration in obese I

Irnawaty Rasyid ${ }^{1}$, Rachmad Soegih ${ }^{1}$, Dante Saksono Harbuwono ${ }^{2}$

\begin{abstract}
Background: The increased prevalence of obesity will bring a great impact in health sector, due to effect of the influence of organ in the body such as type 2 diabetes mellitus (T2DM) and cardiovascular disease (CVD). Reduced energy diet and exercise are effective for management weight loss. During the restriction diet, an obese person should increase the amount of dietary fiber up to 20-35 g/day, specifically of soluble fiber, to more effective fat loss and to improve serum high-density lipoprotein (HDL) and triglyceride (TG) cholesterol concentration. Psyllium husk $(P H)$ is a source of natural soluble fiber obtained from plantago ovata Forssk seed. Objective: The aim of the study were investigated the change of body weight, serum HDL cholesterol, and $T G$ concentration in obese I after supplemented PH $8.4 \mathrm{~g} /$ day and balanced-deficit calories diet (BDCD) for 4 weeks. Method: The survey used double blind randomized clinical trial with parallel design. Subjects were randomly divided into two groups; treatment (T) group and plasebo (P) group. The T subjects received psyllium husk (PH) $8.4 \mathrm{~g} /$ day and BDCD 1200 kcal/day and the P subjects received placebo and BDCD $1200 \mathrm{kcal} /$ day. The analyzed used independent t-test and Mann-Whitney. Results: $A$ total 28 subjects (14 subjects in each group) had completed the intervention. There were no serious adverse effects reported during the intervention. Intake of dietary fiber in T group was $17.2 \pm 2.8 \mathrm{~g} /$ day had significantly higher than P group 8.6 (5.2-15.2) g/day, although supplemented with PH didn't meet the recommendation of fiber intake (20-35 g/day). Decrease of body weight was $-1,8$ $\pm 0,8 \mathrm{~kg}$ and triglyceride level was $-1,5(-416-77)$ in $T$ group that statistically insignificant difference $(p=0,39$ and $p=0,84)$ with $P$ group $-1,6 \pm 0,9 \mathrm{~kg}$ and $-10,0 \pm 31,3$. Soluble supplementation (P group) increased serum HDL cholesterol concentration was $0,0 \pm 4,3 \mathrm{mg} / \mathrm{dL}$ that statistically insignificant difference $(p=0,86)$ with T group $-0,4 \pm 5,9$. Conclusion: PH supplementation $8.4 \mathrm{~g} /$ day and BDCD $1200 \mathrm{kcal} /$ day in obese I can not reduce body weight, serum high-density lipoprotein cholesterol, and triglyceride concentration level in 4 weeks.
\end{abstract}

KEY WORDS: psyllium husk, balanced deficit calories diet, body weight, high-density lipoprotein cholesterol, triglyceride, obese I

\begin{abstract}
ABSTRAK
Latar belakang: Peningkatan prevalensi obesitas dapat mengakibatkan peningkatan angka morbiditas dan mortalitas karena akumulasi jaringan adiposa berlebihan dapat meningkatkan risiko kardiometabolik. Tata laksana obesitas yang paling efektif adalah modifikasi gaya hidup yaitu pengaturan diet dan aktivitas fisik. Penurunan BB dapat menurunkan risiko kardiometabolik, salah satunya ditandai dengan menurunnya kadar trigliserida (TG) dan meningkatnya high-density lipoprotein (HDL) darah. Psyllium husk (PH) adalah salah satu serat larut dari tanaman Plantago ovata Forssk yang sering digunakan sebagai suplementasi karena efek sampingnya yang minimal. Tujuan: Mengetahui perubahan berat badan, kadar kolesterol HDL, dan TG pada penyandang obes I dengan suplementasiserat PH 8,4 g/hari dan diet rendah kalori seimbang(DRKS) 1.200 kkal/hari selama 4 minggu. Metode: Penelitian dengan desain uji klinis paralel acak tersamar ganda. Secara random subjek dibagi menjadi dua kelompok; kelompok perlakuan (KP) dan kelompok kontrol (KK). Subjek KP mendapat PH 8,4 g/hari dan DRKS sedangkan KK mendapat plasebo dan DRKS. Analisis data menggunakan uji t tidak berpasangan dan Mann-Whitney. Hasil: Sejumlah 28 subjek (KP dan KK masing-masing 14) yang mengikuti penelitian hingga selesai, tidak dilaporkan efek samping berbahaya selama perlakuan. Asupan serat subjek belum mencukupi anjuran (20-35 g/hari), yaitu KP 17,2 $\pm 2,8 \mathrm{~g} /$ hari dan KK 8,6 (5,2-15,2) g/hari walaupun dengan suplementasi PH. Pada KP, penurunan BB $-1,8 \pm 0,8 \mathrm{~kg}$ dan TG $-1,5(-416-77) \mathrm{mg} / \mathrm{Dl}$ lebih besar tidak signifikan ( $\mathrm{p}=0,39 \mathrm{and}$ $\mathrm{p}=0,84)$ dibandingkan penurunan $\mathrm{BB}-1,6 \pm 0,9 \mathrm{~kg}$ dan TG $-10,0 \pm 31,3 \mathrm{mg} / \mathrm{dL}$ pada KK. Perubahan kadar kolesterol HDL serum
\end{abstract}

\footnotetext{
Korespondensi: Departemen Ilmu Gizi Fakultas Kedokteran Universitas Indonesia, Jl. Salemba Raya No.6, Jakarta Pusat, DKI Jakarta, Indonesia, e-mail: irna.ak@ gmail.com

2 Divisi Metabolik Endokrin, Departemen Ilmu Penyakit Dalam, Fakultas Kedokteran Universitas Indonesia / Rumah Sakit Umum Pusat Nasional Dr. Cipto Mangunkusumo, J1. Salemba Raya No.6, Jakarta Pusat, DKI Jakarta 10430, Indonesia, Telp (021) 3907703, e-mail: danteid@yahoo.com
} 
yang relatif tetap pada $\mathrm{KP} 0,0 \pm 4,3 \mathrm{mg} / \mathrm{dL}$ dan menurun pada $\mathrm{KK}-0,4 \pm 5,9 \mathrm{mg} / \mathrm{dL}$ tetapi tidak berbeda signifikan ( $\mathrm{p}=0,86$ ). Simpulan: Suplementasi PH 8,4 g/hari dan DRKS $1200 \mathrm{kkal} /$ hari selama 4 minggu tidak lebih baik dalam menurunkan BB, kadarHDL, dan TG dibandingkan plasebo dan DRKS $1200 \mathrm{kkal} / \mathrm{hari}$ penyandang obes I.

KATA KUNCI: serat larut Psyllium husk, diet rendah kalori seimbang, berat badan, kadar HDL, kadar TG, obes I

\section{PENDAHULUAN}

Obesitas merupakan salah satu masalah kesehatan global dengan prevalensi cenderung meningkat di berbagai belahan dunia. World Health Organization (WHO) pada tahun 2010 mencatat prevalensi obesitas di dunia besarnya $11 \%$ dan sedikitnya terdapat 2,8 juta orang yang meninggal akibat obesitas setiap tahunnya (1). Prevalensi obesitas untuk kategori usia lebih dari 18 tahun menurut Riset Kesehatan Dasar (Riskesdas) tahun 2010 sebesar 23,3\% (2). Data ini meningkat dari tahun 2007 sebesar 21,7\% (3). Daerah Khusus Ibukota (DKI) Jakarta merupakan provinsi yang memiliki jumlah penyandang obesitas kelima terbesar di Indonesia yaitu 16,8\% (2). Hasil medical check up dari 6000 orang pegawai yang bekerja di lingkungan DKI Jakarta tahun 2010 adalah $33,32 \%$ merupakan penyandang obesitas (4).

Obesitas adalah suatu kondisi kelebihan massa lemak tubuh yang dapat mengakibatkan kematian karena adanya akumulasi jaringan adiposa berlebihan di dalam tubuh sehingga dapat meningkatkan risiko kardiometabolik pada berbagai penyakit seperti dislipidemia, diabetes mellitus tipe 2 (DMT2), penyakit kardiovaskuler (PKV), dan lain-lain (5). Dalam tata laksana obesitas, yang paling efektif salah satunya adalah modifikasi gaya hidup yaitu pengaturan diet dan aktivitas fisik (6,7). The National Heart, Lung, and Blood Institute (NHLBI) merekomendasikan penurunan energi sebesar 500-1000 kkal/hari untuk menurunkan berat badan (BB) 0,5-1 kg/minggu. Penurunan BB dapat menurunkan risiko kardiometabolik, salah satunya ditandai dengan menurunnya kadar trigliserida (TG) dan meningkatnya kadar high-density lipoprotein (HDL) darah (8). Penelitian menunjukkan kesulitan untuk menentukan apakah peningkatan kadar kolesterol HDL darah berhubungan secara langsung dengan risiko PKV, mengingat peningkatan kadar kolesterol HDL darah mempengaruhi kadar lipoprotein lainnya. Namun, kadar kolesterol HDL merupakan prediktor risiko kardiometabolik yang baik. Upaya menurunkan kadar TG darah dan meningkatkan kadar kolesterol HDL darah merupakan salah satu tujuan sekunder dari terapi pencegahan risiko PKV (9).

Selama menjalankan diet, penyandang obesitas dianjurkan untuk meningkatkan asupan serat sesuai dengan angka kecukupan serat harian (10) karena penyandang obesitas cenderung mengkonsumsi makanan tinggi lemak dan padat energi serta kurang serat (11). Data epidemiologi dan kohort mengindikasikan bahwa asupan makanan tinggi serat berhubungan dengan BB dan indeks massa tubuh (IMT) rendah serta insiden dislipidemia, PKV, dan DMT2 yang juga rendah (11-15). Asupan serat pada penduduk di Indonesia diperkirakan 10,5 g/hari (16), yang masih jauh dari angka kecukupan serat bagi orang Indonesia dewasa yang berkisar 20-35 g/hari (17).

Psyllium husk (PH) adalah salah satu serat larut yang sering digunakan sebagai suplementasi karena efek sampingnya yang minimal (18). Food and Drug Administration (FDA) telah menerima klaim manfaat PH dengan dosis minimal 1,7 g/saji dalam 4 saji/hari untuk pencegahan risiko PKV (19), tetapi hasil penelitian mengenai pengaruh suplementasi $\mathrm{PH}$ terhadap BB serta kadar kolesterol HDL dan TG darah masih bervariasi. Pemberian PH $36 \mathrm{~g} /$ hari dan diet seimbang ad libitum selama 12 minggu pada penyandang $\mathrm{BB}$ lebih-obes dewasa secara signifikan menurunkan BB dan kadar TG darah, tetapi tidak signifikan meningkatkan kadar kolesterol HDL darah (20). Sementara itu, pemberian suplementasi PH 10,5 g/hari dengan diet rendah lemak dan kolesterol dibandingkan plasebo (serat tak larut hemiselulosa dan lignin 10,5 g/hari) yang diberikan pada laki-laki dewasa BB lebih-obes dengan penyakit jantung iskemik (PJI) selama 24 minggu ( 8 minggu intervensi pertama, 8 minggu wash-out, 8 minggu menyilang) signifikan meningkatkan kadar kolesterol HDL darah, tetapi tidak signifikan menurunkan BB dan kadar TG darah (21).

Penelitian tentang pengaruh suplementasi serat larut PH dan diet rendah kalori seimbang (DRKS) 
terhadap obesitas belum pernah dilakukan di Indonesia. Berdasarkan uraian di atas, maka tujuan penelitian ini adalah untuk mengetahui pengaruh suplementasi serat larut PH dan DRKS terhadap BB, kadar kolesterol HDL, dan TG serum pada obesitas.

\section{BAHAN DAN METODE}

Penelitan ini merupakan uji klinis acak tersamar ganda, paralel, dua kelompok, pada penyandang obesitas dengan membandingkan kelompok perlakuan (KP) yang mendapat suplementasi serat larut $\mathrm{PH} 8,4 \mathrm{~g} /$ hari dan DRKS1.200 kkal/hari dibandingkan kelompok kontrol (KK) yang mendapat plasebo dan DRKS $1.200 \mathrm{kkal} /$ hari, yang diberikan sebanyak 3 kali sehari selama 4 minggu berturut-turut. Penelitian dilaksanakan di Balai Kota Pemerintah Provinsi Daerah Khusus Ibukota (DKI) Jakarta pada bulan Juni - Juli 2013. Populasi target adalah seluruh individu penyandang obesitas. Populasi terjangkau adalah seluruh pegawai penyandang obesitas yang bekerja di lingkungan Pemerintah Provinsi DKI Jakarta. Subjek penelitian adalah bagian dari populasi terjangkau yang memenuhi kriteria inklusi yaitu laki-laki dan perempuan dengan usia 30-50 tahun penyandang obes I (IMT 25-29,9 $\mathrm{kg} / \mathrm{m}^{2}$ ) yang bekerja di lingkungan Balai Kota Pemerintah Provinsi DKI Jakarta pada bulan Juni 2013. Kriteria eksklusi antara lain sedang mengikuti program penurunan berat badan; mendapat pengobatan dislipidemia maupun obat yang mempengaruhi metabolisme lemak; diabetes mellitus (DM); hipotiroidisme; memiliki riwayat penyakit jantung koroner minimal 6 bulan terakhir; menderita tukak lambung; terdapat gangguan fungsi hati dan ginjal; hamil dan menyusui; serta mengalami anemia. Sementara itu, kriteria dropout antara lain selama periode penelitian subjek menderita sakit yang memerlukan perawatan di rumah sakit; subjek menolak untuk melanjutkan penelitian; dan subjek mengkonsumsi produk kurang dari $80 \%$. Pada pemeriksaan penyaring, calon subjek diwajibkan berpuasa 12 jam sebelum dilakukan pemeriksaan laboratorium gula darah puasa (GDP), hemoglobin (Hb), kadar kolesterol HDL, dan kadar TG serum.

Perhitungan besar sampel pada uji klinis ini dihitung dengan menggunakan rumus standar untuk uji
Tabel 1. Komposisi isi serat larut Psyllium husk dari Enesis ${ }^{\circledR}$ (per sachet)

\begin{tabular}{lcc}
\hline \multicolumn{1}{c}{ Kandungan } & $\begin{array}{c}\text { Kelompok } \\
\text { perlakuan }\end{array}$ & $\begin{array}{c}\text { Kelompok } \\
\text { kontrol }\end{array}$ \\
\hline $\begin{array}{l}\text { Plantago ovata semini endosperm } \\
\text { pulveratum (psyllium husk) }(\mathrm{g})\end{array}$ & 2,8 & 0 \\
Inulin chicory (g) & 0,96 & 0,96 \\
$\begin{array}{l}\text { Citrus sinensis fructus exactum } \\
\text { siccum (mg) }\end{array}$ & 70 & 70 \\
Sacharosa (g) & 1,05 & 1,05 \\
Vitamin C (mg) & 60 & 60 \\
$\begin{array}{l}\text { Aspartam (mg) } \\
\text { (ADI: } 50 \mathrm{mg} / \mathrm{kg} \mathrm{BB})\end{array}$ & 80 & 80 \\
\hline
\end{tabular}

hipotesis terhadap rerata dua populasi independen (22). Namun, karena tidak diperoleh nilai simpang baku dari selisih rerata mengenai suplementasi serat larut $\mathrm{PH}$ dan DRKS $1.200 \mathrm{kkal} /$ hari terhadap BB, kadar kolesterol HDL, dan TG serum pada obes I dari kepustakaan dan penelitian, maka studi ini merupakan studi pendahuluan dan ditetapkan besar sampel 10 subjek untuk masingmasing kelompok (23). Dengan memperkirakan angka drop out sebesar $20 \%$, maka besar yang diperlukan untuk masing-masing kelompok adalah 12 subjek. Subjek kemudian dibagi menjadi 2 kelompokyaitu KP (15 orang) dan KK (16 orang) dengan randomisasi blok.

Variabel independen adalah suplementasi PH dan DRKS sedangkan variabel dependen yaitu BB, kadar HDL, dan kadar TG. Psyllium husk (PH) adalah serat larut yang berasal dari sekam biji tanaman Plantago ovata Forsk yang memiliki kandungan seperti pada Tabel 1 yang akan diberikan pada KP. Suplementasi PH diberikan seminggu sekali (21 sachet/minggu) kepada subjek yang dikonsumsi sebanyak 3 x 1 sachet/hari dan diminum 15 menit sebelum sarapan, makan siang, dan makan malam, dengan cara dilarutkan dalam $250 \mathrm{~mL}$ air, diaduk hingga rata selama lebih kurang 1 menit, dan diminum segera setelah diaduk sebelum larutan mengental. Suplementasi yang diberikan dalam bentuk bubuk di sachet dan dibuat serupa disiapkan oleh PT. Sari Enesis Indah, Bekasi.

Diet rendah kalori seimbang (DKRS) pada penelitian ini adalah DRKS 1.200 kkal berdasarkan kebutuhan energi harian per individu per hari, dengan komposisi karbohidrat 50-60\%, lemak 25-35\%, dan protein $15-20 \%$. Pada penelitian ini, subjek penelitian 
diberi panduan berupa menu harian yang diberikan setiap 7 hari dan subjek penelitian kemudian mempersiapkan makanannya di rumah berdasarkan panduan tersebut. Diet rendah kalori seimbang $1.200 \mathrm{kkal} / \mathrm{hari}$ ini sesuai dengan yang direkomendasikan oleh National Heart Lung and Blood Institute (NHLBI) dan National Cholesterol Education Program-Adult Treatment Panel III (NCEPATP III) $(8,24)$. Subjek juga diberikan informasi mengenai jumlah, ukuran, dan pembagian porsi makanan sesuai dengan menu diet yang diberikan.

Pengukuran antropometri yang meliputi BB, TB, dan IMT dilakukan di awal dan akhir penelitian dengan menggunakan instrumen penelitian yaitu SECA digital scale dan microtoise. Pengukuran BB dilakukan pada awal, kontrol per minggu, dan akhir penelitian. Setiap pengukuran dilakukan sebanyak 2 kali kemudian data yang diambil adalah rerata dari hasil pengukuran tersebut. Hasil pengukuran digunakan untuk menentukan status gizi subjek berdasarkan IMT yang dikategorikan sesuai dengan kriteria Asia Pasifik yaitu obes I jika IMT $25-29,9 \mathrm{~kg} / \mathrm{m}^{2}(25)$. Kadar kolesterol HDL serum subjek juga diukur sebanyak 2 kali yaitu sebelum dan setelah perlakuan dengan metode spektrofotometri dengan reagen HDL cholesterol Bayer menggunakan alat Advia 1800. Demikian juga dengan pengukuran kadar TG dengan metode spektrofotometri dengan reagen TG dari Bayer menggunakan alat Advia 1800. Pengukuran dilaksanakan di Laboratorium Prodia bagian penelitian. Alur penelitian secara lengkap dapat dilihat pada Gambar 1.

Selain itu, data yang diperoleh pada awal dan akhir penelitian yaitu asupan energi, makronutrien, serat, dan air, serta tingkat aktivitas fisik. Data asupan makanan diperoleh dengan metode food recall $1 \times 24$ jam dan food record 3 x 24 jam melalui wawancara dan pencatatan. Pada awal penelitian, dilakukan food recall 1 x 24 jam untuk mengetahui asupan makan sebelum diberikan perlakuan dengan menanyakan jenis, cara memasak, dan perkiraan jumlah makanan yang dikonsumsi menggunakan ukuran rumah tangga (URT) dan bantuan food model. Selama penelitian, subjek diminta untuk mengisi buku catatan harian (food record) mengenai jenis dan jumlah makanan dan minuman yang dikonsumsi dalam 3 x 24 jam (2 hari kerja dan 1 hari libur). Pada saat kontrol mingguan, dilakukan wawancara asupan makanan untuk validasi data dengan metode food recall 1 x 24 jam. Selanjutnya, data asupan makan, termasuk jumlah asupan serat dikonversikan ke dalam ukuran gram (g) menggunakan daftar analisis bahan makanan dan dianalisis dengan perangkat lunak nutrisurvey. Asupan energi adalah besarnya jumlah kalori yang dikonsumsi subjek per hari dibandingkan dengan kebutuhan energi total (KET) per individu. KET adalah jumlah kebutuhan energi basal (KEB), termal effect of food (TEF), dan aktivitas fisik (AF) masing-masing individu (26). Asupan makronutrien (karbohidrat, lemak, dan protein) yang diperoleh dari makanan sehari-hari tersebut kemudian diukur dengan menghitung persentase rerata asupan terhadap energi total. Tingkat aktivitas fisik adalah semua kegiatan fisik subjek yang meliputi pekerjaan, kebiasaan olahraga, dan kegiatan di waktu luang (27) yang diukur menggunakan kuesioner kemudian dikategorikan menjadi aktivitas rendah ( $\leq 9$ poin); aktivitas sedang (9-15 poin); dan aktivitas tinggi ( $\geq 15$ poin).

Penentuan normalitas data dilakukan dengan menggunakan uji normalitas data Saphiro-Wilk. Data yang menunjukkan distribusi normal $(\mathrm{p}>0,05)$ disajikan dalam bentuk rerata dan simpang baku, distribusi tidak normal $(\mathrm{p}<0,05)$ disajikan nilai median dan rentangan (minimummaksimum). Uji t tidak berpasangan digunakan untuk menilai hubungan antara dua variabel, jika syarat tidak terpenuhi maka digunakan uji Mann-Whitney. Penelitian ini telah mendapat persetujuan dari Komite Etik Fakultas Kedokteran Universitas Indonesia.

\section{HASIL}

Sebanyak tiga puluh enam orang subjek yang bersedia mengikuti penelitian dengan menandatangani lembar persetujuan, tetapi berdasarkan kriteria penolakan sebanyak 5 orang tidak dapat diikutsertakan dalam penelitian. Hal ini disebabkan dari hasil pemeriksaan laboratorium penyaring diketahui kadar gula darah puasa (GDP) $\geq 126 \mathrm{mg} / \mathrm{dL}$ pada 3 orang calon subjek dan kadar $\mathrm{Hb}$ $<12$ g/dL pada 2 orang calon lainnya. Penelitian ini diikuti oleh 31 subjek yang dibagi menjadi 2 kelompok yaitu 15 orang KP dan 16 orang KK. Pada akhir perlakuan hanya diperoleh data lengkap dari 28 orang subjek penelitian karena selama masa perlakuan 3 orang dikeluarkan 


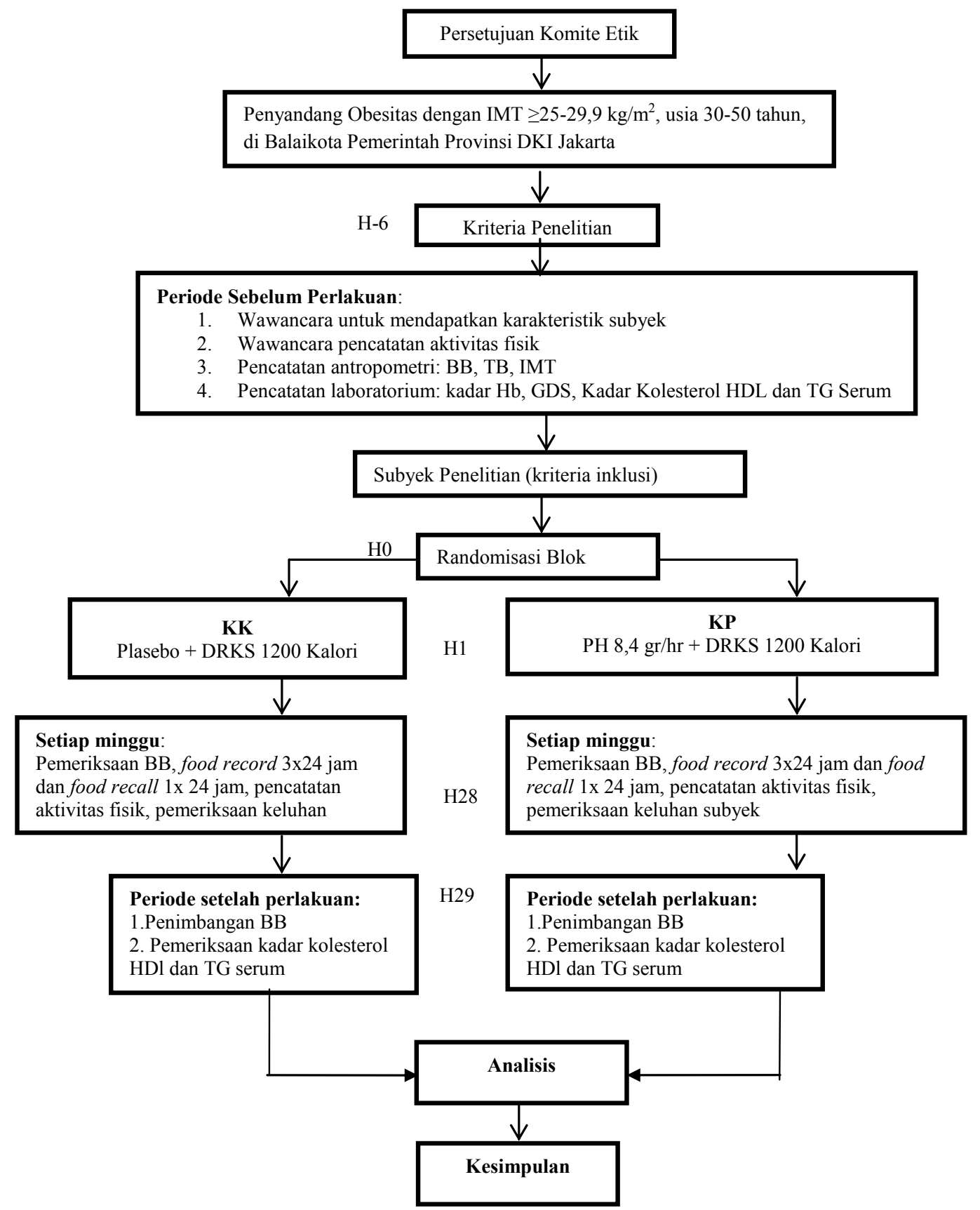

Gambar 1. Bagan alur penelitian

akibat lost to follow-up (1 orang dari KP dan 2 orang dari KK) (Gambar 2). Berdasarkan Tabel 2 diketahui karakteristik subjek penelitian (usia, tinggi badan, berat badan, IMT, kadar HDL dan TG) kedua kelompok dapat dibandingkan karena tidak terdapat perbedaan signifikan pada karakteristik subjek ( $\mathrm{p}>0,05)$.
Komposisi asupan energi dan makronutrien sesuai dengan anjuranDRKS $1.200 \mathrm{kkal} / \mathrm{hari}$, tetapi asupan saturated fatty acid (SAFA) lebih tinggi serta asupan serat, polyunsaturated fatty acid (PUFA), dan mono-unsaturated fatty acid (MUFA) lebih rendah dari anjuran yang telah direkomendasikan pada kedua kelompok. Persentase 


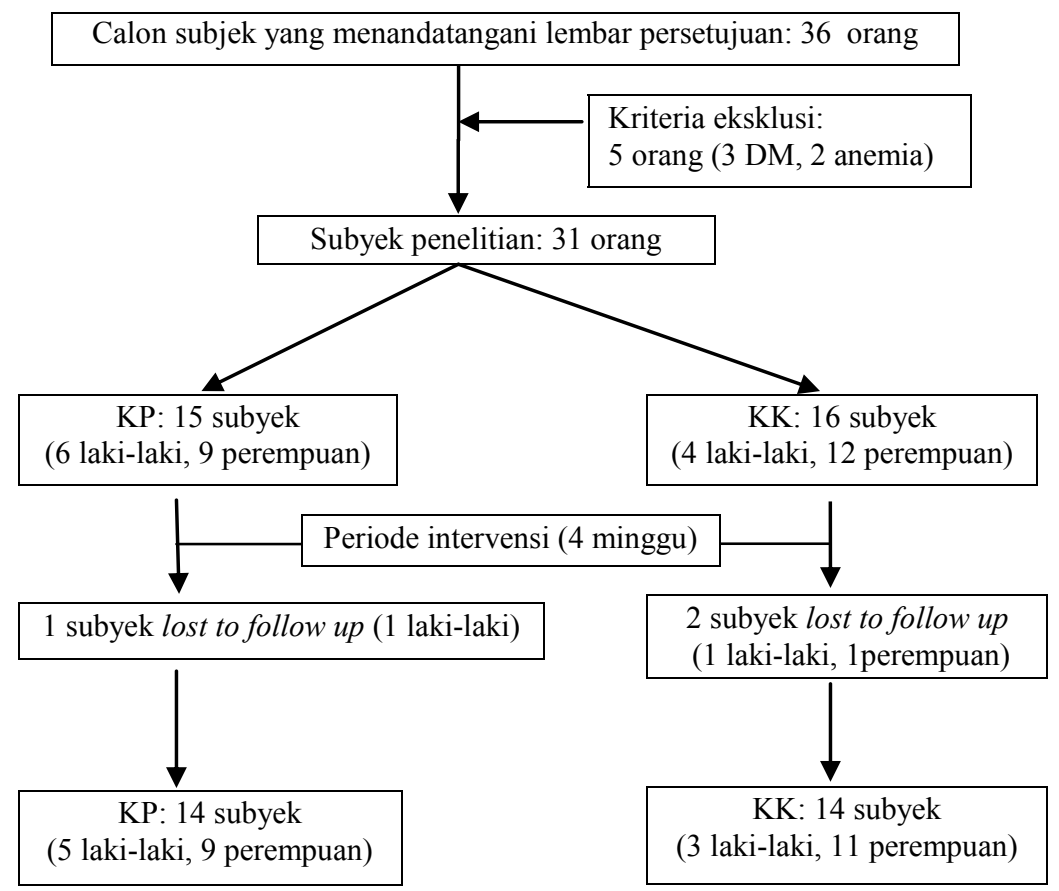

Gambar 2. Alur seleksi subjek penelitian

Tabel 2. Karakteristik subjek awal penelitian

\begin{tabular}{|c|c|c|c|}
\hline Karakteristik & $K P(n=14)$ & $K K(n=14)$ & $\mathbf{p}^{*}$ \\
\hline \multicolumn{4}{|l|}{ Jenis kelamin } \\
\hline Laki-laki & 5 & 3 & 0,68 \\
\hline Perempuan & 9 & 11 & \\
\hline \multicolumn{4}{|l|}{ Tingkat pendidikan } \\
\hline Sedang & 3 & 4 & 1,00 \\
\hline Tinggi & 11 & 10 & \\
\hline \multicolumn{4}{|l|}{ Jenis pekerjaan } \\
\hline Administrasi & 13 & 14 & 1,00 \\
\hline Medis & 1 & 0 & \\
\hline \multicolumn{4}{|c|}{ Riwayat obes dalam keluarga } \\
\hline Ada & 10 & 7 & 0,44 \\
\hline Tidak ada & 4 & 7 & \\
\hline Usia (tahun) & $35,0(30-45)^{\dagger}$ & $34,5(30-48)^{\dagger}$ & 0,81 \\
\hline Tinggi badan $(\mathrm{cm})$ & $161,1 \pm 8,9$ & $157,8 \pm 6,6$ & 0,27 \\
\hline Berat badan $(\mathrm{kg})$ & $73,1 \pm 8,8$ & $67,7 \pm 6,2$ & 0,07 \\
\hline $\operatorname{IMT}\left(\mathrm{kg} / \mathrm{m}^{2}\right)$ & $28,0 \pm 1,1$ & $27,2 \pm 1,4$ & 0,07 \\
\hline $\begin{array}{l}\text { Kadar kolesterol } \\
\text { HDL }(\mathrm{mg} / \mathrm{dL})\end{array}$ & $47,6 \pm 12,2$ & $47,1 \pm 9,6$ & 0,92 \\
\hline Kadar TG (mg/dL) & $\begin{array}{c}114,0 \\
(47-718)\end{array}$ & $105,4 \pm 50,9$ & 0,29 \\
\hline
\end{tabular}

$\mathrm{KP}=$ kelompok perlakuan; $\mathrm{KK}=$ kelompok kontrol; *signifikan $(\mathrm{p}<0,05) ; \mathrm{IMT}=$ indeks massa tubuh; $\mathrm{HDL}=$ high-density lipoprotein; $\mathrm{TG}=$ trigliserida; Nilai dalam rerata $\pm \mathrm{SD} ; \uparrow$ Median (minimummaksimum), pada kedua kelompok. asupan energi dan karbohidrat total berbeda signifikan antara KP dan KK. Asupan KH pada penelitian ini telah sesuai anjuran, tetapi asupan jenis KH simpleks (sukrosa) pada KP $(11,5 \pm 5,4 \%)$ lebih tinggi dari yang dianjurkan yaitu kurang dari 10\% dari total energi harian. Konsumsi KH simpleks berdasarkan analisis asupan yaitu sukrosa lebih tinggi signifikan $(\mathrm{p}<0,01)$ pada KP 35,6 $(8,3-69,9)$ $\mathrm{g} /$ hari atau 11,5 $\pm 5,4 \%$ dibandingkan pada KK 13,8 $(3,4-55,5) \mathrm{g} /$ hari atau $6,0(1,3-24,2) \%$ dari energi total. Demikian juga dengan ssupan serat pada penelitian ini setelah suplementasi PH pada KP 17,2 $\pm 2,8 \mathrm{~g} /$ hari lebih tinggi signifikan $(\mathrm{p}<0,01)$ dibandingkan $\mathrm{KK} 8,6(5,2-15,2)$ $\mathrm{g} /$ hari. Asupan energi subjek pada penelitian ini direstriksi menjadi $1.200 \mathrm{kkal} /$ hari dengan komposisi karbohidrat 50-60\%, lemak $25-35 \%$, dan protein $15-20 \%$. Rerata asupan energi subjek pada KP adalah 1.130,9 $\pm 221,9$ $\mathrm{kkal} /$ hari atau 94,2 $\pm 18,5 \%$ dari preskripsi diet yang dianjurkan dan pada KK sebesar 1.024,3 \pm 269,9 kkal/ hari atau $85,4 \pm 22,9 \%$ (Tabel 3). Asupan tersebut masih dalam batas yang direkomendasikan oleh NHLBI (24) sebesar 1.000-1.200 kkal/hari. Asupan kalori sebesar $1.000-1.200 \mathrm{kkal} /$ hari dengan komposisi seimbang masih 
Tabel 3. Asupan kedua kelompok sebelum dan sesudah perlakuan

\begin{tabular}{|c|c|c|c|c|c|c|}
\hline \multirow{2}{*}{ Asupan zat gizi } & \multicolumn{2}{|c|}{ Sebelum perlakuan } & \multirow[b]{2}{*}{$\mathbf{p}$} & \multicolumn{2}{|c|}{ Setelah perlakuan } & \multirow[b]{2}{*}{$\mathbf{p}$} \\
\hline & KP & KK & & KP & KK & \\
\hline \multicolumn{7}{|l|}{ Energi (kkal/hari) } \\
\hline Asupan recall & $1306,6 \pm 443,7$ & $1353,2 \pm 532,1$ & 0,80 & $1084,5 \pm 272,9$ & $1055,4 \pm 298,4$ & 0,59 \\
\hline Asupan record & & & & $1130,9 \pm 221,9$ & $1024,3 \pm 269,9$ & $0,02 *$ \\
\hline$\%$ kebutuhan & $69,2 \pm 17,4$ & $77,2 \pm 29,8$ & 0,39 & $60,8 \pm 11,4$ & $59,0 \pm 13,2$ & 0,31 \\
\hline$\%$ anjuran & & & & $94,2 \pm 18,5$ & $85,4 \pm 22,9$ & $0,02 *$ \\
\hline Karbohidrat (kkal/hari) & $725,1 \pm 210,1$ & $732,2 \pm 357,2$ & 0,95 & $613,1 \pm 134,5$ & $545,7 \pm 161,1$ & $0,02 *$ \\
\hline$\%$ kebutuhan & $38,5 \pm 8,2$ & $41,8 \pm 20,3$ & 0,58 & $32,6(22,4-54,0)^{\dagger}$ & $31,3 \pm 9,0$ & 0,27 \\
\hline$\%$ anjuran & $56,8 \pm 7,9$ & $52,6 \pm 10,5$ & 0,25 & $54,6 \pm 8,3$ & $53,7 \pm 10,4$ & 0,61 \\
\hline Serat (g/hari) & $6,8 \pm 3,2$ & $5,3 \pm 3,2$ & 0,24 & $17,2 \pm 2,8$ & $8,6(5,2-15,2)^{\dagger}$ & $<0,01^{*}$ \\
\hline$\%$ anjuran & $33,9 \pm 16,1$ & $26,6 \pm 16,0$ & 0,24 & $85,8 \pm 13,9$ & $42,9(26,0-76,0)^{\dagger}$ & $<0,01^{*}$ \\
\hline Protein (kkal/hari) & $185,3 \pm 91,9$ & $196,0 \pm 65,0$ & 0,73 & $174,8(87,2-463,2)^{\dagger}$ & $159,9 \pm 46,9$ & 0,97 \\
\hline$\%$ kebutuhan & $9,8 \pm 4,2$ & $11,2 \pm 3,8$ & 0,35 & $9,3(5,1-27,7)^{\dagger}$ & $9,1 \pm 2,3$ & 0,46 \\
\hline$\%$ anjuran & $13,8 \pm 3,6$ & $15,2 \pm 3,4$ & 0,29 & $15,5(10,5-27,7)^{\dagger}$ & $15,7 \pm 3,0$ & 0,89 \\
\hline Lemak (kkal/hari) & $\begin{array}{c}375,8 \\
(155,7-942,3)^{\dagger}\end{array}$ & $\begin{array}{c}395,5 \\
(183,6-983,7) \dagger\end{array}$ & 0,91 & $335,9 \pm 108,3$ & $314,9 \pm 129,9$ & 0,35 \\
\hline$\%$ kebutuhan & $20,6 \pm 9,2$ & $21,1(10,3-55,9)^{\dagger}$ & 0,73 & $18,0 \pm 5,5$ & $16,6(5,0-87,3)^{\dagger}$ & 0,90 \\
\hline$\%$ anjuran & $28,9 \pm 7,9$ & $30,7 \pm 10,2$ & 0,61 & $31,3(12,7-43,8)^{\dagger}$ & $30,5 \pm 8,6$ & 0,53 \\
\hline SAFA (kkal/hari) & $115,8 \pm 101,3$ & $154,8 \pm 111,3$ & 0,33 & $123,2 \pm 63,2$ & $119,4 \pm 70,0$ & 0,75 \\
\hline$\%$ kebutuhan & $5,08(0,25-13,4)^{\dagger}$ & $8,9 \pm 6,2$ & 0,14 & $6,7 \pm 3,5$ & $6,8 \pm 3,3$ & 0,84 \\
\hline$\%$ anjuran & $8,6 \pm 6,7$ & $11,4 \pm 6,3$ & 0,26 & $10,8 \pm 5,3$ & $11,9 \pm 5,5$ & 0,29 \\
\hline PUFA (kkal/hari) & $27,5(2,7-295,2)^{\dagger}$ & $67,1(19,8-299,7)^{\dagger}$ & 0,16 & $53,6(9,0-155,7)^{\dagger}$ & $45,9(9,9-176,4)^{\dagger}$ & 0,36 \\
\hline$\%$ kebutuhan & $1,3(0,2-12,5)^{\dagger}$ & $3,7(1,1-17,0)^{\dagger}$ & 0,15 & $3,1 \pm 1,6$ & $2,6(0,6-9,7)^{\dagger}$ & 0,57 \\
\hline$\%$ anjuran & $1,9(0,3-12,5)^{\dagger}$ & $4,4(1,5-15,3)^{\dagger}$ & 0,16 & $4,6(1,0-11,4)^{\dagger}$ & $4,1(0,9-11,5)^{\dagger}$ & 0,91 \\
\hline MUFA (kkal/hari) & $70,7 \pm 59,8$ & $88,8 \pm 54,9$ & 0,41 & $73,9 \pm 31,6$ & $61,2(14,4-162,0)^{\dagger}$ & 0,06 \\
\hline$\%$ kebutuhan & $3,7 \pm 3,0$ & $5,0 \pm 3,1$ & 0,26 & $3,9 \pm 1,8$ & $3,5(0,9-8,9)^{\dagger}$ & 0,14 \\
\hline$\%$ anjuran & $5,1 \pm 3,7$ & $6,8 \pm 3,5$ & 0,23 & $6,7(1,3-10,3)^{\dagger}$ & $6,4 \pm 2,7$ & 0,49 \\
\hline Kolesterol (mg/hari) & $83,1(0,0-630,3)^{\dagger}$ & $198,5(0,0-1285,8)^{\dagger}$ & 0,19 & $154,4(13,0-770,3)^{\dagger}$ & $128,5(0,0-496,2)^{\dagger}$ & 0,35 \\
\hline Air (mL) & $1841,7 \pm 339,9$ & $\begin{array}{c}1957,3 \\
(1080,0-2217,1)^{\dagger} \\
\end{array}$ & 0,57 & $\begin{array}{c}1798,5 \\
(1183,7-2629,8)^{\dagger} \\
\end{array}$ & $\begin{array}{c}1823,8 \\
(1106,3-4747,1)^{\dagger} \\
\end{array}$ & 0,99 \\
\hline
\end{tabular}

*Signifikan $(\mathrm{p}<0,05)$; Nilai dalam rerata $\pm \mathrm{SD} ; \dagger$ Median (minimum-maksimum), pada kedua kelompok

dapat mencukupi kebutuhan metabolisme basal (28). Defisit energi selama penelitian dihitung berdasarkan data food recall sehingga diperoleh hasil defisit energi pada KP lebih rendah dibandingkan dengan defisit pada $\mathrm{KK}$, masing-masing pada KP sebesar 282,0 $\pm 482,6 \mathrm{kkal} /$ hari dan pada KK sebesar 331,8 $\pm 578,3 \mathrm{kkal} /$ hari tetapi tidak ada perbedaan yang signifikan $(\mathrm{p}=0,62)$ antara kedua kelompok.

Sebelum penelitian, aktivitas fisik pada kedua kelompok KP dan KK tidak ada perbedaan yang signifikan. Setelah penelitian, indeks olahraga pencatatan aktivitas fisik pada KK lebih tinggi signifikan ( $\mathrm{p}=0,04)$ dibandingkan pada $\mathrm{KP}$, tetapi kedua kelompok masih termasuk dalam kategori aktivitas fisik yang rendah $(\leq 9)$ (Tabel 4).
Perubahan BB dan IMT sedikit lebih banyak pada KP dibandingkan KK, tetapi paramater-parameter tersebut tidak berbeda signifikan antara kedua kelompok. Kadar kolesterol HDL dan TG serum akhir KP dan KK setelah pemberian suplementasi serat larut $\mathrm{PH}$ dan DRKS selama 4 minggu berturut-turut juga dapat dilihat di Tabel 5. Kadar akhir dan perubahan kadar kolesterol HDL dan TG serum tidak berbeda signifikan antara kedua kelompok.

\section{BAHASAN}

Suplementasi serat larut PH sebesar $8,4 \mathrm{~g} /$ hari dan diet rendah kalori seimbang $1.200 \mathrm{kkal} / \mathrm{hari}$ 
Tabel 4. Nilai pencatatan aktivitas fisik antara KP dan KK sebelum dan setelah perlakuan

\begin{tabular}{lcccccc}
\hline \multicolumn{1}{c}{ Aktivitas fisik } & \multicolumn{2}{c}{ Sebelum } & perlakuan & \multirow{2}{*}{ Setelah perlakuan } & \multicolumn{2}{c}{ P } \\
& KP & KK & $\mathbf{p}$ & KP & KK & \\
\hline Indeks pekerjaan & $2,3 \pm 0,5$ & $2,4 \pm 0,5$ & 0,85 & $2,6 \pm 0,5$ & $2,7(1,8-3,4) \dagger$ & 0,34 \\
Indeks olahraga & $2,4 \pm 0,7$ & $2,6 \pm 0,8$ & 0,43 & $2,3(0,0-3,7) \dagger$ & $2,6(1,3-4,5) \dagger$ & $0,04^{*}$ \\
Indeks waktu senggang & $2,6 \pm 0,5$ & $2,8 \pm 0,6$ & 0,38 & $2,8(1,8-4,0)$ & $2,8 \pm 0,7$ & 0,85 \\
\hline
\end{tabular}

*signifikan $(\mathrm{p}<0,05)$; Nilai dalam rerata $\pm \mathrm{SD} ; \uparrow$ Median (minimum-maksimum)

Tabel 5. Rerata nilai awal, akhir, dan perubahan antropometri serta kadar kolesterol HDL dan TG serum antara kelompok perlakuan dan kontrol

\begin{tabular}{lccc}
\hline \multicolumn{1}{c}{ Variabel } & $\mathbf{K P}(\mathbf{n}=\mathbf{1 4})$ & $\mathbf{K K}(\mathbf{n}=\mathbf{1 4})$ & $\mathbf{p}$ \\
\hline BB $(\mathrm{kg})$ & & & \\
Nilai awal & $73,1 \pm 8,8$ & $67,7 \pm 6,2$ & 0,07 \\
Nilai akhir & $71,2 \pm 8,3$ & $66,2 \pm 6,3$ & 0,08 \\
Perubahan & $-1,8 \pm 0,8$ & $-1,6 \pm 0,9$ & 0,39 \\
Kolesterol HDL (mg/dL) & & \\
Kadar awal & $47,6 \pm 12,2$ & $47,1 \pm 9,6$ & 0,92 \\
Kadar akhir & $47,6 \pm 10,5$ & $46,8 \pm 8,9$ & 0,83 \\
Perubahan & $0,0 \pm 4,3$ & $-0,4 \pm 5,9$ & 0,86 \\
TG (mg/dL) & & \\
Kadar awal & $114,0(47-718) \dagger$ & $105,4 \pm 50,9$ & 0,29 \\
Kadar akhir & $110,5(46-305) \dagger$ & $95,4 \pm 51,7$ & 0,07 \\
Perubahan & $-1,5(-416-77) \dagger$ & $-10,0 \pm 31,3$ & 0,84 \\
\hline
\end{tabular}

Nilai dalam rerata $\pm \mathrm{SD} ; \uparrow$ Median (minimum - maksimum)

selama 4 minggu berturut-turut yang telah dilakukan pada penelitian ini tidak dapat menurunkan BB, kadar HDL, dan TG dengan signfikan. Penurunan BB sedikit lebih banyak pada $\mathrm{KP}(-1,8 \pm 0,8 \mathrm{~kg})$ dibandingkan $\mathrm{KK}$ $(-1,6 \pm 0,9 \mathrm{~kg})$, tetapi perbedaan ini tidak signifikan. Perbedaan penurunan BB yang sedikit lebih tinggi pada KP dibandingkan KK dan tidak signifikan ini hampir sama dengan penelitian yang dilakukan di Spanyol (29). Berdasarkan data food recall diperoleh hasil penurunan energi pada KP lebih rendah dibandingkan dengan KK (282,0 \pm 482,6 kkal/hari vs 331,8 $\pm 578,3 \mathrm{kkal} / \mathrm{hari})$, tetapi tidak ada perbedaan yang signifikan $(p=0,62)$ antara kedua kelompok. Penurunan BB yang terjadi pada kedua kelompok sesuai dengan rekomendasi dari NHBLI yaitu defisit energi sebesar 300-500 kkal/hari pada obes I menghasilkan penurunan BB 300-500 g/ minggu (24,30).

Penelitian menunjukkan pengaruh suplementasi serat makanan terhadap regulasi energi masih kontroversi. Meta-analisis menyebutkan penggunaan serat larut guar gum tidak efektif menurunkan $\mathrm{BB}$ dan sering menyebabkan gangguan saluran cerna. Suplementasi serat lainnya pun masih belum menghasilkan kesimpulan yang definitif terkait peranannya dalam regulasi BB. Namun, serat larut PH diketahui memiliki efek samping yang paling sedikit dibandingkan serat larut lainnya dan saat ini masih terus diteliti mengenai perannya terhadap BB. Penelitian skala besar lainnya menunjukkan bahwa suplementasi serat larut $\mathrm{PH}$ dalam waktu singkat (3 minggu) menghasilkan penurunan BB yang tidak berbeda signifikan dibandingkan kontrol (29). Penelitian sebelumnya di Australia memberikan suplementasi serat larut yang lebih besar dan durasi penelitian yang lebih lama (12 minggu) dari penelitian ini, tetapi lebih singkat dibandingkan penelitian di Spanyol yaitu menghasilkan penurunan signifikan BB dibandingkan kontrol $(20,29)$.

Penelitian ini menghasilkan perubahan kadar kolesterol HDL serum yang relatif tetap pada KP $(0,0 \pm$ $4,3 \mathrm{mg} / \mathrm{dL})$ dan terjadi penurunan pada $\mathrm{KK}(-0,4 \pm 5,9)$ $\mathrm{mg} / \mathrm{dL}$ tetapi tidak menunjukkan perbedaan signifikan. Faktor-faktor yang diketahui berperan terhadap kadar kolesterol HDL serum adalah asupan makanan, gen, 
karakteristik individu (usia dan jenis kelamin), BB, dan aktivitas fisik (31). Perubahan kadar kolesterol HDL pada penelitian ini mungkin disebabkan asupan energi dan KH yang lebih rendah signifikan pada KK, konsumsi karbohidrat sederhana atau simpleks pada KP lebih tinggi signifikan dibandingkan pada KK, sementara defisit energi lebih sedikit pada KP. Meningkatnya asupan KH simpleks akan lebih cepat meningkatkan sintesis very low density lipoprotein (VLDL) di hati dibandingkan KH kompleks sehingga dapat menurunkan kadar HDL darah $(32,33)$. Selain itu, hasil penelitian ini menunjukkan asupan serat yang rendah pada kedua kelompok. Asupan serat pada penelitian ini setelah suplementasi $\mathrm{PH}$ pada KP $(17,2 \pm$ 2,8 g/hari) lebih tinggi signifikan dibandingkanKK $(8,6$ $(5,2-15,2) \mathrm{g} /$ hari). Penelitian menunjukkan bahwa asupan serat penduduk dewasa di Indonesia sebesar 10,5 g/orang/ hari dan di DKI Jakarta 9,9 g/orang/hari (16) sedangkan pada penelitian ini asupan serat awal sebelum penelitian lebih rendah (KP 6,8 $\pm 3,2 \mathrm{~g} /$ hari vs KK 5,3 $\pm 3,2 \mathrm{~g} /$ hari) sehingga dengan diberikan suplementasi serat larut $\mathrm{PH}$ sebanyak 8,4 g/hari ini masih kurang dari anjuran asupan serat untuk orang dewasa di Indonesia (20-35 g/hari) (17). Selama penelitian ini diketahui bahwa suplementasi serat tetap tidak mencukupi rekomendasi AKG sehingga tidak terlihat pengaruhnya pada profil lipid.

Hasil penelitian ini hampir sama dengan penelitian di Spanyol dan Australia (20,29). Setelah 16 minggu, hasil penelitian di Spanyol menunjukkan bahwa tidak terdapat perbedaan yang signifikan kadar kolesterol HDL serum antara subjek yang mendapat campuran serat larut dibandingkan dengan kontrol (29). Sementara itu, penelitian di Australia menyatakan bahwa suplementasi serat larut PH $36 \mathrm{~g} /$ hari pada diet sehat ad libitum selama 12 minggu tidak menghasilkan perbaikan kadar HDL serum dibandingkan dengan kontrol (20). Hal ini mungkin karena tingkat aktivitas fisik subjek yang hampir sama pada kedua kelompok penelitian. Pada kedua penelitian di atas, tingkat aktivitas fisik tidak dijelaskan karena intervensi hanya menitikberatkan pada diet dan suplementasi serat larut. Pada penelitian ini, nilai indeks olahraga lebih tinggi signifikan pada KK dibandingkan $\mathrm{KP}$, tetapi tingkat aktivitas fisik kedua kelompok subjek tergolong dalam kategori aktivitas fisik rendah $(\leq 9)$ (27) sehingga tidak mempengaruhi hasil dari penelitian ini. Nilai yang berpengaruh adalah minimal kategori aktivitas fisik sedang (9-15) sesuai dengan rekomendasi dari NCEP-ATP III yaitu aktivitas fisik yang dianjurkan adalah olahraga secara teratur minimal 30 menit sebanyak 3-5 kali dalam seminggu dapat menurunkan BB dan memperbaiki kadar kolesterol HDL dan TG dalam 4-6 bulan $(8,27)$. Berbeda dengan penelitian lain di Spanyol yang menghasilkan peningkatan kadar kolesterol HDL serum berbeda signifikan dibandingkan dengan kontrol. Penelitian ini dilakukan dengan desain menyilang dengan kolesterol HDL serum sedikit lebih rendah, yaitu 43,3 $\pm 10,4 \mathrm{mg} / \mathrm{dL}$ pada $\mathrm{KP}$ dan $42,5 \pm 7,7 \mathrm{mg} / \mathrm{dL}$ pada $\mathrm{KK}$. Penelitian di Spanyol tersebut mampu mempengaruhi beberapa profil lipid, tetapi mekanisme mempengaruhi profil lipid tersebut masih belum diketahui secara pasti (21).

Penurunan TG lebih banyak pada KK $(10,0$ $\pm 31,3 \mathrm{mg} / \mathrm{dL})$ dibandingkan KP (-1,5 (-416-77)mg/ $\mathrm{dL})$, tetapi tidak berbeda signifikan. Perubahan kadar TG pada penelitian ini hampir sama dengan penelitian sebelumnya di Spanyol (22). Hal ini mungkin karena kadar TG awal pada penelitian ini dan penelitian tersebut tidak terlalu tinggi sehingga perubahan kadar TG tidak berbeda signifikan. Perubahan kadar TG akhir ini lebih banyak pada KK dibandingkan KP. Hal ini dapat disebabkan oleh asupan energi KP yang lebih besar dibandingkan KK atau defisit energi lebih besar pada KK dibandingkan KP serta asupan KH yang lebih rendah signifikan pada $\mathrm{KK}$, mengingat konsumsi jenis $\mathrm{KH}$ simpleks pada KP lebih tinggi signifikan dibandingkan pada KK. Peningkatan asupan KH, terutama jenis $\mathrm{KH}$ simpleks lebih cepat meningkatkan sintesis VLDL di hati sehingga dapat meningkatkan kadar TG $(32,33)$. Selain itu, pada penelitian ini menunjukkan asupan serat yang rendah pada kedua kelompok, padahal seperti yang diketahui beberapa sifat dari serat larut diantaranya dapat menurunkan kadar lemak serta menghambat absorpsi lemak makanan dengan cara mengikat empedu dan meningkatkan ekskresinya melalui tinja (34) sehingga hal ini diduga turut mempengaruhi kadar TG secara tidak langsung.

Penelitian di Australia yang memberikan suplementasi serat larut lebih banyak menunjukkan bahwa terjadi penurunan signifikan kadar TG serum setelah 6 dan 
12 minggu perlakuan dibandingkan dengan kontrol (20). Penelitian tersebut sejalan dengan penelitian di Amerika Serikat yang dilakukan selama 6 minggu pada subjek DMT2 mengandung tinggi serat total $50 \mathrm{~g} /$ hari dengan serat larut berjumlah $25 \mathrm{~g}$ /hari dapat menurunkan kadar TG serum 10,2\% (20,35). Penelitian lainnya di Spanyol menemukan penurunan kadar TG serum pada subjek yang diberi serat larut PH kira-kira setengah dari penurunan dengan terapi obat penurun kolesterol (simvastatin) yaitu $10-16 \%$ (21). Oleh karena itu, pemberian suplementasi PH dapat dipertimbangkan sebagai terapi tambahan pada subjek hipertrigliseridemia sedang. Meskipun mekanisme penurunan kadar TG ini tidak diketahui secara pasti, tetapi diduga terjadi karena penurunan absorbsi TG dan karbohidrat di usus halus (36). Penelitian di Australia menemukan tidak terdapat perbedaan signifikan kadar TG serum pada kelompok yang mendapat total serat yang jauh lebih tinggi, yaitu kelompok serat dan diet sehat ad libitum (asupan serat $>55 \mathrm{~g} /$ hari) dibandingkan dengan kelompok diet sehat ad libitum saja (asupan serat $31 \mathrm{~g}$ /hari) (20). Hal ini menunjukkan bahwa asupan serat yang bersumber dari bahan makanan efektif dalam mempengaruhi kadar TG serum.

Keterbatasan pada penelitian ini yang perlu diperbaiki adalah lama penelitian, dosis suplementasi serat yang rendah, dan juga metode penilaian asupan energi. Beberapa penelitian yang telah dilakukan sebelumnya pada umumnya menggunakan waktu penelitian lebih lama dari penelitian ini, diharapkan dengan memperpanjang waktu penelitian dapat diperoleh hasil yang lebih baik dalam meningkatkan kadar kolesterol HDL serum serta menurunkan BB dan kadar TG serum.

\section{SIMPULAN DAN SARAN}

Pemberian suplementasi Psyllium husk sebesar 8,4 g/hari dan diet rendah kalori seimbang $1.200 \mathrm{kkal} /$ hari pada penyandang obes I selama 4 minggu tidak lebih lebih baik dalam menurunkan BB, kadar HDL, dan kadar TG serum dibandingkan dengan plasebo dan diet rendah kalori seimbang1.200 kkal/hari. Penelitian selanjutnya mengenai pengaruh suplementasi serat larut, peneliti menyarankan untuk meningkatkan dosis suplementasi serat, menambah durasi penelitian, menambah jumlah subjek yang lebih besar, memilih subjek yang mengalami peningkatan kadar TG darah dan atau penurunan kadar kolesterol HDL darah, serta meningkatkan aktivitas fisik.

\section{RUJUKAN}

1. World Health Organisation. Fact sheets-obesity and overweight. [series online] 2012 [cited 28 Oktober 2012]. Available from: URL: http://www.who.int/mediacentre/ factsheets/fs311/en/

2. Litbangkes Departemen Kesehatan Republik Indonesia. Riset kesehatan dasar.[series online] 2010 [cited 28 Oktober 2012]. Available from: URL: http://www. riskesdas.litbang.depkes.go.id/2010/

3. Litbangkes Departemen Kesehatan Republik Indonesia. Riset kesehatan dasar. [series online] 2007 [cited 28 Oktober 2012]. Available from: URL: http://www.litbang. depkes.go.id/bl_riskesdas2007

4. Dinas Kesehatan DKI Jakarta. Data medical check up. Jakarta: Dinas Kesehatan DKI Jakarta; 2010.

5. Després JP, Lemieux I, Bergeron J, Pibarot P, Mathieu P, Larose E, Rodés-Cabau J, Bertrand OF, Poirier P.Abdominal obesity and the metabolic syndrome: contribution to global cardiometabolic risk. Arterioscler Thromb Vasc Biol 2008;28(6):1039-49.

6. Champe PC, Harvey RA, Ferrier DR. Obesitas. Dalam: Champe PC, Harvey RA, Ferrier DR, editor. Biokimia ulasan bergambar (Lippincott's Illustrated Review: Biochemistry). Edisi ke 3. Jakarta: EGC; 2010.

7. Gee M, Mahan LK, Escott-Stump S. Weight management. Dalam: Mahan LK, Escott-Stump S, editor. Krause's food \& nutrition therapy. Edisi ke 12. Canada: Elsevier; 2008.

8. National Cholesterol Education Program-Adult Treatment Panel III. Detection, evaluation, and treatment of high blood cholesterol in adults. [series online] 2002 [cited 31 Januari 2013]. Available from: URL: http://www.nhlbi.nih. gov/guidelines/cholesterol/atp3full.pdf

9. Brunzell JD, Davidson M, Furberg CD, Goldberg RB, Howard BV, Stein JH, Witztum JL; American Diabetes Association; American College of Cardiology Foundation. Lipoprotein management in patients with cardiometabolic risk: consensus statement from the American Diabetes Association and the American College of Cardiology Foundation. Diabetes Care 2008;31(4):811-22.

10. Kushner RF. Evaluation and management of obesity. In: Fauci AS, Kasper DL, Longo DL, Braunwald E, Hauser SL, Jameson JL, editor. Harrison's principles internal medicine. Edisi ke 17. New York: McGraw Hill; 2008.

11. Slavin JL. Dietary fiber and body weight. Nutrition 2005;21(3):411-8. 
12. Howarth NC, Saltzman E, Roberts SB. Dietary fiber and weight regulation. Nutr Rev 2001;59(5):129-39.

13. Lairon D. Dietary fiber and control of body weight. Nutr Metab Cardiovasc Dis 2007;17(1):1-5.

14. Ludwig DS, Pereira MA, Kroenke CH, Hilner JE, Van Horn L, Slattery ML, Jacobs DR Jr.Dietary fiber, weight gain, and cardiovascular disease risk factors in young adults. JAMA 1999;282(16):1539-46.

15. Kromhout D, Bloemberg B, Seidell JC, Nissinen A, Menotti A.Physical activity and dietary fiber determine population body fat levels: the Seven Countries Study. Int J Obes Relat Metab Disord 2001;25(3):301-6.

16. Jahari AB, Sumarno I. Epidemiologi konsumsi serat di Indonesia. Maj Gizi Indon 2001;25:37-56.

17. Kartono D, Hardinsyah, Jahari AB, Sulaeman A, Soekatri M. Penyempurnaan kecukupan gizi untuk orang Indonesia. Dalam: Widya Karya Pangan dan Gizi X; 2012. Jakarta: LIPI; 2012.

18. Singh B. Psyllium as therapeutic and drug delivery agent. Int J Pharm 2007;334(1-2):1-14.

19. Food Drug Administration. Control of health claims in foods. The Lancet 1998;351:609.

20. Pal S, Khossousi A, Binns C, Dhaliwal S, Ellis V. The effect of a fibre supplement compared to a healthy diet on body composition, lipids, glucose, insulin and other metabolic syndrome risk factors in overweight and obese individuals. Br J Nutr 2011;105(1):90-100.

21. Sola R, Godas G, Ribalta J, Vallvé J-C, Girona J, Anguera A, Ostos M, Recalde D, Salazar J, Caslake M, Martín-Luján F, Salas-Salvadó J, Masana L. Effects of soluble fiber (Plantago ovata husk) on plasma lipids, lipoproteins, and apolipoproteins in men with ischemic heart disease. Am J Clin Nutr 2007;85(4):1157-63.

22. Madiyono B, Moeslichan S, Sastroasmoro S, Budiman I, Purwanto SH. Perkiraan besar sampel. Dalam: Sastroasmoro S, Ismael S, editor. Dasar-dasar metodologi penelitian klinis. Edisi ke 4. Jakarta: Sagung Seto; 2011.

23. Birkett MA, Day SJ. Internal pilot studies for estimating sampel size. Stat Med 1994;13(23-24):2455-63.

24. National Heart, Lung, and Blood Institute (NHLBI). The practical guide indentification, evaluation, and treatment of overweight and obesity in adults. [series online] 2000 [cited 31 Januari 2013]. Available from: URL: http://www. nhlbi.nih.gov/files/docs/guidelines/prctgd_c.pdf
25. Nishida C. Appropriate body-mass index for Asian populations and its implications for policy and intervention strategies. Lancet 2004;363(9403):157-63.

26. Sulaeman A, Setiawan B, Permaesih D, Apriantini A, Afriansyah N. Angka kecukupan gizi. Dalam: Widya Karya Pangan dan Gizi VII; 2004. Jakarta: LIPI; 2004.

27. Baecke JA, Burema J, Fritjers JE. A short questionnaire for the measurement of habitual physical activity in epidemiological studies. Am J Clin Nutr 1982;36(5):93642.

28. Strychar I. Diet in the management of weight loss. CMAJ 2006;174(1):56-63.

29. Salas-Salvado J, Farres X, Luque X, Narejos S, Borrell M, Basora J, Anguera A, Torres F, Bulló M, Balanza R; Fiber in Obesity-Study Group.Effect of two doses of a mixture of soluble fibres on body weight and metabolic variables in overweight or obese patients: a randomised trial. $\mathrm{Br} \mathrm{J}$ Nutr 2008;99(6):1380-7.

30. Astrup A. Dietary management of obesity. J Parenter Enteral Nutr 2008;32(5):575-7.

31. National Heart, Lung, and Blood Institute (NHLBI). High blood cholesterol: what you need to know. [series online] 2005 [cited 5 September 2013]. Available from: URL:http://www.nhlbi.nih.gov/health/public/heart/chol/ wyntk.htm

32. Melanson K, Dwyer J. Popular diets for treatment of overweight and obesity. Dalam: Wadden TA, Stunkard AJ, editor. Handbook of obesity treatment. Edisi ke 2. New York: Guilford Press; 2002.

33. Gallagher ML. The nutrients and their metabolism. In: Mahan L, Escott-StumpS, editor. Krause's food and nutrient therapy. Edisi ke-12. Canada: Elsevier; 2008.

34. Gropper S, Smith J, Groff J. Fiber. Dalam: Adams P, Lustig A, Feldsman E, Downs E, editor. Advanced nutrition and human metabolism. Edisi ke-5. USA: Wadsworth Cengange Learning; 2009.

35. Chandalia M, Garg A, Lutjohann D, von Bergmann K, Grundy SM, Brinkley LJ. Beneficial effects of high dietary fiber intake in patients with type 2 diabetes mellitus. N Engl J Med 2000;342(19):1392-8.

36. Ebihara K, Schneeman BO. Interaction of bile acids, phospholipids, cholesterol, and triglyseride with dietary fiber in the small intestine of rats. J Nutr 1989;119(8):1100-6. 